\title{
IAMJ
}

INTERNATIONAL

AYURVEDIC

MEDICAL JOURNAL

\section{AYURVEDIC MANAGEMENT OF ORAL HERPES W.S.R. TO PITHAJA MUKHA- PAKA - A SINGLE CASE REPORT}

\author{
Premcy C. R $^{1}$, Ahalya $\mathbf{S}^{2}, \mathbf{S}$ M Pasha ${ }^{3}$ \\ ${ }^{1}$ PG scholar, Dept. of PG Studies in Shalakya Tantra, G.A.M.C, Bengaluru, Karnataka, India \\ ${ }^{2}$ Principal, G.A.M.C, Bengaluru, Karnataka, India \\ ${ }^{3}$ H.O.D. \& Associate professor, Dept. of PG Studies in Shalakya Tantra, G.A.M.C, Bengaluru, Karnataka, India
}

Corresponding Author: premcy85@,gmail.com

\section{https://doi.org/10.46607/iamj2609032021}

(Published online: March 2021)

Open Access

(C) International Ayurvedic Medical Journal, India 2021

Article Received: 19/02/2021 - Peer Reviewed: 26/02/2021 - Accepted for Publication: 04/03/2021

Check for updates

\begin{abstract}
Introduction: Herpes simplex is a viral infection caused by the herpes simplex virus. Oral herpes causes the group of blisters called cold sores or fever blisters over the face or mouth. These are having severe burning sensation which causes the dysphagia and difficulty in speaking. It is associated with fever. There will be ulcer formation by the rupture of blisters. Oral herpes can be correlated to Pithaja mukhapaka. This is a case report of 41 years old male who complained of severe burning ulcers on hard palate since 1 month. Materials and Methods: The subject who approached Shalakya Tantra OPD of GAMC, with symptoms of burning ulcers over the palate was thoroughly examined and treatment was planned based on Chikitsa sutra of Pithaja mukhapaka. Result: The subject had shown good improvement both subjectively and objectively. Discussion: Pithaja mukhapaka is a Sarvasara Mukharoga with Daha, Oshayuktha Vrana. There for the treatment is focused on pacifying Pitha.
\end{abstract}

Keywords: Pithaja mukhapaka, herpes simplex, Guluchyadi kashayam.

\section{INTRODUCTION}

Herpes simplex viruses are the members of Herpes Viridae family. Among them the Herpes simplex is a viral infection caused by the herpes simplex virus. Infections are categorized based on the part of the body infected. ${ }^{1}$ Oral herpes involves the region of face or mouth. It causes the formation of group of blisters often called as cold sores or fever blisters. These causes sore throat. There will be formation of ulcers by the rupture of blisters. It will cause severe burning sensation, dysphagia and difficulty in speaking. Genital 
herpes, often simply known as herpes, may have minimal symptoms or form blisters that break open and result in small ulcers ${ }^{2}$. Before the appearance of blisters, there will be tingling or shooting pain. Based on the symptoms mentioned in ayuvedic classics, Oral herpes can be correlated to Pithaja Mukhapaka which is a Sarvasra mukharoga.

\section{Materials and Methods}

Case Report: basic information of the patient, Age: 41 years, Sex: male, Religion: Hindu, Occupation: clerk

Chief complaints: 2 ulcers in the right side of hard palate associated with severe burning sensation for 1 month. He was suffering from fever during the first week. History of present illness: The patient complaint of ulcers in the right side of hard palate for one month. He was suffering from fever during the first week. After that he started burning pain in the palate. While observing the painful area of palate he noticed hyperemia which turns into painful blisters within two days. After two days the blisters breaks opened and turned to ulcers. The ulcers were associated with severe burning sensation. The burning sensation was increased during speaking and swallowing. On consulting a general physician, he was diagnosed to have Oral Herpes Simplex and underwent treatment for the same. But he didn't get any relief. Past history: nothing significant, Family history: nothing significant, Personal history: bowel -regular, Appetite-good, Micturition- 5-6 times/day, Sleep -good, Examination: nadi- 78/min, Mutra -5-6 times/day, Mala -regular, Jihwa -Liptha, Shabda-Prakrutha, SparshaUshna, Druk -Prakrutha, Akruthi -Madhyama, Prakruthi - Pitha Kapha, Vitals - normal, B.P 124/80mm of H g., RS - on auscultation no murmur sound detected, CVS-NAD, CNS-NAD

Oral examination: as shown in table.1.

Investigations: shown in table number 2 .

Treatment: Patient was given treatment for a period of 30 days. He had undergone Sadyo Virechana with Avipathi churna $30 \mathrm{gm}$ along with $20 \mathrm{ml}$ of Draksha Kashayam as Virechanopaga, Further patient was administered orally with Guduchyadi kashyam $15 \mathrm{ml}$ (BD), Shankha bhasma (1pinch) BD, Laghu suthasekar ras (2 bd) as Shamana aushadha.

Result: After, a treatment period of 30 days patient was relieved from symptoms. As shown in the table no: 3. There is relief from ulcer as shown in the Figure 1.a) before and b) after treatment.

\section{DISCUSSION}

Here oral herpes is correlated with Mukhapaka. Shodhana followed by Shamana line of treatment are adopted here. Shodhana in the form of Sadyo Virechana with Avipathi Churna and Draksha Kashaya was given for Pitha Virechana on the first day. Virechana was given to reduce the speed of Sara Guna of Pitha by expelling the Bahu Pitha Dosha. After sadyo virechana, burning sensation during speaking was slightly reduced. After of Shodhana, Oushadhis like Guluchyadi Kashaya, Shankha Bhasma and Lagusootha Shekhara Rasa were given for the Shamana of remaining Pitha Doshas. In classics Pitha Raktha Hara line of treatment are mentioned for Pithaja Mukhapaka. Here Guluchyadi kashaya is Raktha Pithahara and Dahagna in action. Laghu sootha shekhara Rasa is Pithahara and Kleda Hara. Shankha Bhasma is Pitha Hara and Dahagna in action. After 30 days, during follow up period burning sensation, hyperemia and both ulcers were absent.

\section{Probable Mode of Action:}

a) Virechana: Sadyo virechana with Avipathi churna $^{3}$ (30gm) and Draksha kashaya as Sahapana was given. Which expels the Bahu Pitha dosha, thus in turns reduces the symptoms.

b) Guduchyadi kashayam ${ }^{4}$ : It consist of Guduchi, Padmaka, Arishtaka, Dhanyaka, Raktha chandana, which are having Pitha Raktha hara, Jwara hara, Dahagna and Agnikruth action.

c) Shanka Bhasma ${ }^{5}$ : having Pitha hara action, it reduces Daha or burning sensation.

d) Laghu Susthashekar Ras: It acts on Pithaja mukapaka by its Kleda hara, Pitha hara property. The patient was advised to follow proper Pathya during the treatment period.

\section{CONCLUSION}

Thus, by following Ayurvedic treatment protocol and following Pathya and avoiding Katu, Amla, lavana rasa there was a certain amount of improvement for the patient's condition. Thus, Ayurvedic treatment is cost effective and doesn't have any side effects. 


\section{REFERENCES}

1. https://en.wikipedia.org/wiki/Herpes_simplex_virus

2. Traci C Johnson. Web MD Medical Reference. Aug 28,2020. https://www.webmd.com/genital-herpes/pain-management-herpes\#1

3. K V Krishna Vaidyan. S Gopala Pilla. Sahasra yogam. Sujana Priya Vyakyanam. Churna kalpana. shloka no:73. Vidyarambham Publishers.Alapuzha.2011.jul.30 ${ }^{\text {th }}$ edition. pp:165

4. Vagbhata. Ashtanga Hrdaya English translation by R. Vaidyanath. Publisher Chaukambha Orientalia Varanasi. Vol-1 First Edition. 2007(16/15).pp:202.

5. Sadananda Sharma. Rasa Tarangini. English translation by Ravindra angadi. Chaukambha publishing house. Varanasi. First edition 2015. pp:194

Table: 1

\begin{tabular}{|l|l|l|}
\hline Sl.no: & Structures & Findings \\
\hline 1. & Lips & NAD \\
\hline 2. & Gums & NAD \\
\hline 3. & Teeth & NAD \\
\hline 4. & Hard Palate & $\begin{array}{l}\text { Ulcer } \\
\text { a) Number:2 } \\
\text { b) Size: } 1 \text { cm in diameter, raised edges, centrally depressed } \\
\text { c) Color: pallor } \\
\text { d) Surrounding area: Hyperaemic }\end{array}$ \\
& & e) Pain: Burning \\
\hline 5. & Soft Pallate & Hyperaemic \\
\hline 6. & Tongue & Coated \\
\hline 7. & Buccal Mucosa & NAD \\
\hline
\end{tabular}

Table 2

\begin{tabular}{|l|l|l|}
\hline Sl.no; & Investigations & Readings \\
\hline 1. & Acute phase serum HSV & Positive \\
\hline
\end{tabular}

Table 3:

\begin{tabular}{|l|l|l|l|}
\hline Sl.no: & Symptoms & BT & AT \\
\hline 1. & Ulcer & Present & Absent \\
\hline 2. & Burning sensation & Present & Absent \\
\hline 3. & Fever & Present & Absent \\
\hline 4. & Hyperaemia & Present & Absent \\
\hline
\end{tabular}

Figures:

\begin{tabular}{|l|l|}
\hline & \\
\hline Fig 1: Before Treatment & Fig 2: After treatment. \\
\hline
\end{tabular}

\section{Source of Support: Nil \\ Conflict of Interest: None Declared}

How to cite this URL: Premcy C. R. et al: Ayurvedic Management Of Oral Herpes W.S.R. To Pithaja Mukha-Paka - A Single Case Report. International Ayurvedic Medical Journal \{online\} 2021 \{cited March, 2021\} Available from: http://www.iamj.in/posts/images/upload/674 676.pdf 